\title{
Government Supervision - A Factor for Business Development
}

\author{
Plamena Nedyalkova \\ University of Economics - Varna, Bulgaria
}

Government supervision is a kind of control, that manifests itself through the action of the executive, legislature, and even judiciary. Government supervision affects business by the supervision activities and facilities on the entrepreneurship, accounting and management activities of an organization. Its essence, role and purpose have long been established by society. Despite its recognition, much of the business does not approve the action and interference of the state in business development and the development of micro and macro-enterprises. The purpose of this article is to research and analyze this issue, to be determined why government regulatory supervision has its strengths and weaknesses. The survey was carried out among 28 enterprises in the food industry in Bulgaria, as the influence and impact of government supervision on them was studied.

\section{INTRODUCTION}

The government supervision is directed towards: preservation and safe-keeping of the state property; the proper management of the state property; preservation of the state sovereignty; preservation of the civil rights; democratic conduct of society as a whole with a view to the proper regulation of all state processes and achieving of the optimum state organization for the society (Menifield, 2013).

On the government supervision influences the state mechanism, which manifests through the state apparatus (i.e. the state organizations and the state supervisory and control institutions). The state mechanism represents in one the subject and object of state management. On the other hand, the mechanism of government supervision has to be accepted as a mechanism for carrying out of the state authority. The interpretation of the state authority depends on the fact in what way is adopted the essence and the meaning of the notion "state". Some researchers bind the state authority with the direct influence and impact of the government (Michael Allen \& Brian Thompson, 2008), others adopt the state authority as ,domination of the power and compulsion" (Legal Academy, 2018). We shall not stop our attention in detail on the state authority in this article, and on the problems of the government supervision and its impact on business. Because of this reason, the main purpose of the article is to be presented the problems and perspectives in the development of the government supervision, as the following main tasks are achieved:

1. To be presented the specificities and peculiarities of the preliminary government supervision on the business development.

2. To be disclosed the purpose of the current government supervision on the business development.

3. To be presented the specificities and peculiarities of the subsequent government supervision. 


\section{IMPACT OF THE PRELIMINARY GOVERNMENT SUPERVISION ON THE BUSNESS DEVELOPMENT}

In the contemporary conditions when the technologies anticipate the social necessities of the society, the government supervision has different purpose, it is directed towards the enforcing of contemporary approaches, methods and means through which is aimed to be prognosticated a significant part of the events and situations, which may occur or may have a negative economic effect (Nilsson, 2015). The preventive supervision role of the state supervisory and control institutions is strongest expressed through the dynamically changing legislative acts, which are striving to anticipate the course of events and to enforce the restrictive measures before essential violations are carried out. The precautionary of the government supervision is its most important quality, which is very frequently neglected on behalf of the supervision bodies, but when the preventive approaches and methods of the supervision are not being enforced properly and duly is observed a negative effect on the society and business as a whole (Nedyalkova, 2014).

By the carried out research in Bulgaria among 28 companies of the food industry („Prestige 96“ PLC, Zaharni zavodi PLC, Savimex Single Member LTD, Rior Single Member LTD, „Bread Coop Pavlikeni EAD, „ZAIRA -Z.Z. Single Member LTD , Alpi Commerce, Tandem Popovo LTD, Orehite-G" LTD, United Milk Company" (UMC) - Plovdiv, „Carlsberg Bulgaria“ PLC, Izida LTD, Mondelez Bulgaria Single Member LTD, Milk-Engineering" LTD, "Rositsa Mill " LTD, Tandem LTD, OLINESA PREMIUM“ LTD, DERONI LTD, Winery Targovishte, Vinex Preslav, Winery Karnobat, Winery Stambolovo" Single Member LTD, Todorov PLC, HIPP PLC, Ganchev Single Member LTD, Magic flame Single Member LTD, Hrimak LTD, Sibila 2000" Single Member LTD) is established, 87 \% of the inquired (managers, directors of the indicated companies and chief accountants) indicate, that the preliminary government supervision has exercised significant influence on the starting of the business activity of the company. It was necessary the companies to conform with certain state requirements in advance in order to guarantee that the production activity shall not have unfavourable impact on the environment and waters, and also the companies had to guarantee the workers' and employees' safety, as well as the safety of the population in the populated place, where the main production activity of the company shall be carried out. Another part of the inquired persons, i.e. 13\% have indicated in the inquiry research, that before starting of the business they had to meet a number of administrative state requirements and they do not accept, that there has been carried out a quality preliminary supervision on behalf of the state. The Electronic management strategy for by the government of the Republic of Bulgaria, which was adopted in year 2002, aimed to solve great number of state-administrative problems, but the most significant problem was the establishment of the preliminary government supervision, by more precise determination of the functions and purpose of this type of control. The Electronic management strategy has presented the development of the government supervision in two directions, and namely its globality in the development, perfection and administrative reconstruction of the state administration, and also its optimum variant for resource provision and good practices. Despite the invested over 2 milliard Bulgarian levs in the building of an electronic government in Bulgaria, the results brought out of the carried out researches in 2016 are not encouraging. It turns out that for establishment of a company in Estonia are necessary only 15 minutes, as the company is legalized within the framework of hours, and the entrepreneur can start work in the same day. In Bulgaria are necessary 23 days for starting a business. And already started work, the Bulgarian managers spend $16 \%$ of their time for coping with bureaucratic decrees -2.4 times more than in Estonia.

The government supervision can be presented as a „cyclic process, which includes the consecutive carrying out of the so called main management functions - planning, organizing, motivating and supervision" (Koleva, 2005). This cyclic process is manifested in all forms of manifestation of the

government supervision. The inquired persons have indicated the following problematic spheres at the realization of the preliminary supervision on behalf of the state institutions and the state administration, and namely: 


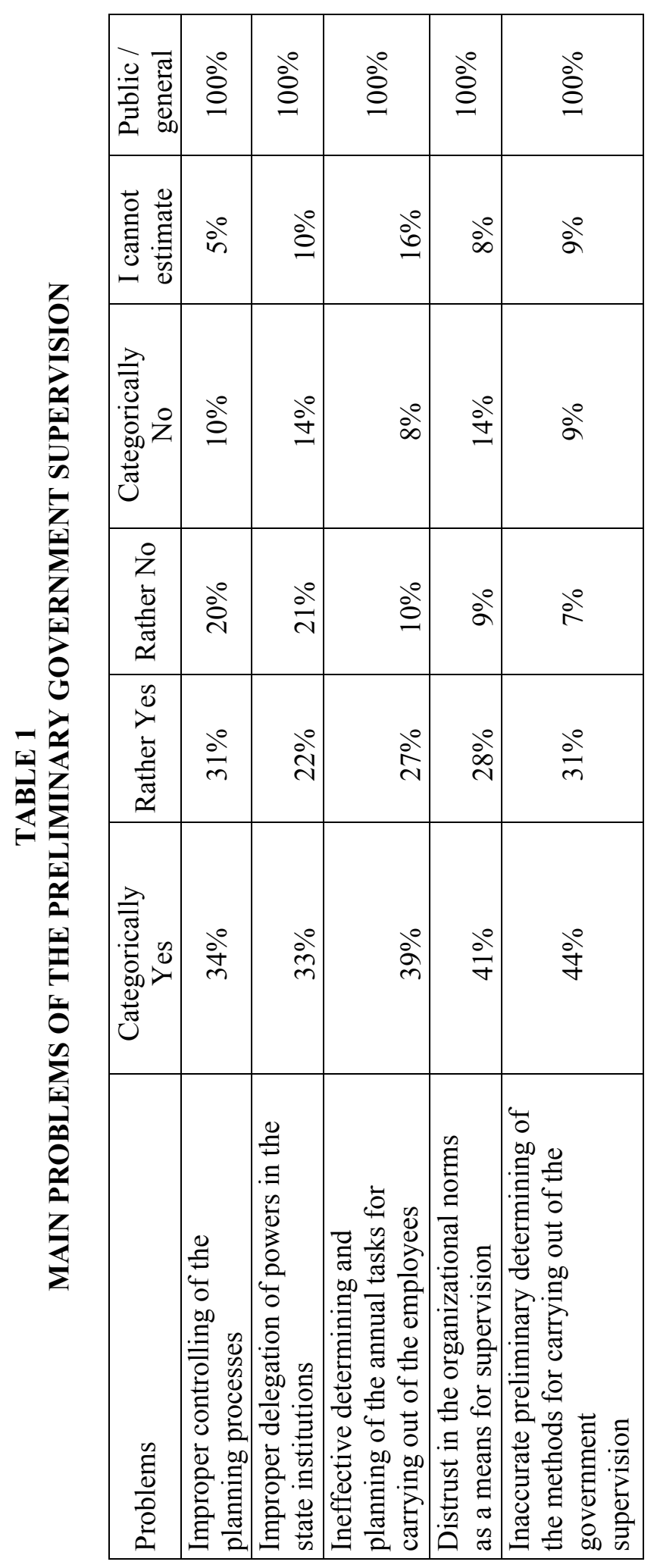

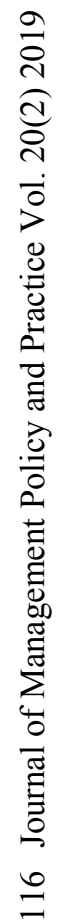


On the grounds of the presented data from table 1 can be drawn the following main conclusions and recommendations for the carrying out of a preliminary government supervision:

1. The improper controlling of the planning processes is a precondition for the admission of significant deviations of the actual results of the preliminarily assigned and specified in the respective standards. Respectively this is a precondition for the improper controlling and determining of the incoming flows of resources, which the organizations of the public and nonpublic sector generate in favour of the state.

2. The improper delegation of the powers of the state institutions - 33\% of the inquired persons have indicated, that this is a significant problem, $22 \%$ have answered categorically „Yes“, $21 \%$ - rather „No“, by categorically „No“ have answered $14 \%$, and barely $10 \%$ cannot estimate. The far too many state institutions with incorrectly determined functions, tasks and powers are a precondition for the rising of bureaucratic problems, which burden the development of business, rather than being a precondition for its development. The next basic problem arises in this relation, and namely the improper determining of the employees' tasks for carrying out. It is very frequently established, that a big part of the available information is present, given on behalf of the business through the information systems of the National Revenue Agency, National Social Security Institute, municipalities and etc., but the information is not processed of quality and the same checkups and reports have to be presented and on a hard copy, besides the already given information on a soft copy.

3. An essential problem of the government supervision is the existing distrust in the organizational norms as a means for supervision.

4. Another substantial problem is the inaccurate preliminary determining of the methods for carrying out of the government supervision.

An essential part of the so indicated problems can be solved on behalf of the state and efficient, quality preliminary government supervision to be achieved by an optimization of the administrative state structures and state institutions (Jae, 2016).

\section{IMPACT OF THE CURRENT GOVERNMENT SUPERVISION ON THE DEVELOPMENT OF THE BUSINESS}

To the current government supervision refers the administrative supervision, judicial supervision, budgetary supervision and etc. I.e. this is the supervision, which is directed mainly towards a checkup of the current condition of the controlled object with purpose establishing the observance of the adopted normative requirements and standards. The impact of the government supervision is strongest and most tangibly perceived namely through the current supervision checkups, current monitoring on the activity of organizations from the public and non-public sector. In this relation, a significant part of the established government supervision approaches through the years have been considerably changed, and others have been changed by newer and more contemporary. These changes are noticed most tangibly in the public sector, as the following newer approaches have been established:

1. The applying of a Weberian approach - this approach has changed the administrativebureaucratic model, established and operating until year 2000, it is directed towards the better management in the public (state) sector, as this ,approach is directed not only towards the efficiency, but also towards the fulfilling of the criteria for legitimacy, transparency, justice, care for the citizens and etc." (Manliev, 2017).

2. The government supervision has to be identified with the established model for management. In the non-public sector the main model of management is directed towards the achieving of maximum profit, with the non-public sector the supervision is directed not towards the profit, and towards the ,proper creation of state goods (wealth) and their most appropriate offering in favour of the society as a whole“ (Bush, 2013).

3. The quasi-market approach of management - this approach of the government supervision resembles the corporative supervision, i.e. the state means and methods to be directed and to 
be applied promptly and adaptively towards the changing environment, as the emphasis is put on ,a study on the citizens' necessities and the society as a whole of the offering of a new type of public services, new type of administrative management with purpose effective and efficient usage of the public goods (wealth)" (Shiplett, 2005).

The strengthened government supervision, directed towards public health services, health social securing, observance of the tax and customs policy, as well as directed towards the complete movement as per the cost-benefit part of the budget, towards preservation the foundations of the state sovereignty is a continuous process, which process for the controlled objects is frequently unexpected, unforeseen and with an unclear end result for the checked organization itself. Out of the 28 studied enterprises of the food industry is established that $57 \%$ have indicated, that they have committed at least one time tax frauds, directed towards decrease of their tax burdens and liabilities towards the state, other part of them $23 \%$ have indicated, that they have committed tax frauds at least two times, which have not been established by the auditing tax control bodies, and the rest part $20 \%$ indicate, that they have committed tax frauds more than three times, as a part of the tax misuses have been established by the tax inspectors, but other part of the misuses have not been found at all on behalf of the tax inspectors. The main reason for committing the tax violations, which the enterprises indicate, is that the tax stakes are high and they prefer not to pay high taxes to the state, and to invest the cash flow in the investment activity of the company.

At the realized research on the impact of the government supervision on 28 enterprises of the food industry was established, that the tax violations and misuses, found by the tax control bodies are due not only to committed violations of the tax laws and tax normative acts, but also are consequence of violations of the accounting standards and accounting policy, committed preliminary.

The technology of the current government supervision, which manifests through the means and methods of supervision, materialized in the respective forms and type of control - check ups, revisions, inspections, audits, control and etc. Is a precondition not only for the disclosure of the weaknesses, misuses and irregularities on behalf of the enterprises at the applying of the normative acts, but thus it serves for assistance of the realization of different investment projects and investment tasks (Iddrisu, 2010). This is most precisely manifested through the respective thematic checkups for the separate enterprise, department,

association or company. The thematic checkups can be organized programmatically-purposefully, for example a checkup of the public procurements, a checkup of the investment project, a checkup of the resources for financing of the investment project and so on. The thematic checkup comprises of several stages: preparation and investigation of the objects; a factual (i.e. tangible) check up; a documentary check up; realization of the results of the carried out control; impact and regulation of the deviations.

\section{IMPACT OF THE SUBSEQUENT CONTROL ON THE BUSINESS DEVELOPMENT}

The subsequent control is realized after the carrying out and conclusion of the economic operations. It is very frequently accepted, that through the subsequent control is carried out a checkup of the preliminary and current control. The subsequent control has the function to secure with additional information the control institutions about the controlled object (Gunn, 2009). This form of control is the most widely spread and is applied by all control organizations, consequently there is not a business unit, which has not been under the scope of the control institutions and which has not been enforced subsequent control on their behalf. The subsequent control in compliance with the operating legislation of Bulgaria influences in certain sequence on all enterprises, organizations, institutions and departments, which in combination with the preliminary and current control creates the complete control system of the country. The distinctive peculiarity of the subsequent control is its completeness, sequence and comprehensiveness.

It has been established by the carried out inquiry research, that $67 \%$ of the inquired indicate, that the subsequent control renders favourable impact, since it helps for improvement of the organizational structure of the organization, significant weaknesses, omissions and misuses are disclosed. 13\% of the inquired people accept, that the subsequent control does not have favourable effect on the development of the business, and the rest $20 \%$ of the inquired cannot estimate the impact of the subsequent control on the development of the business. 
The National Audit Office and the Public Financial Inspection Agency (PFIA) are two institutions, which are authorized to carry out subsequent control on the public procurements. The control, which they realize is subsequent external control, in contrast to the preliminary external control, which is carried out by the Agency For Public Procurements (APP). The main purposes of the subsequent control on behalf of the National Audit Office and PFIA are to be checked the conduct of the assignors of public procurements. In Bulgaria the main assignors of the public procurements are the municipalities, ministries, departments, agencies, and the assignee of the public procurements are the big, average and small enterprises. The basic problems of the enterprises are found at the execution of the public procurements and mostly the problems are manifested during the stages for participation for the public procurement. According to a survey around $10 \%$ of the companies, which execute public procurements in Bulgaria win 70 percent of the procurements. For the period from 2007 until 2015, these are approximately 200 thousand procurements for $\mathbf{6 0}$ milliard Bulgarian levs. The companies are one and the same for the whole country, i.e. a very few other companies and enterprises can win the public procurements. The main problem is that the assignors lay down certain condition, which can be covered only by certain enterprises and thus only these enterprises win the public procurements. The purpose of the government supervision, which is realized through the Public Financial Inspection Agency and the National Audit Office, is to be prevented misuses and not to be allowed this vicious practice to transform into a permanent tendency.

The National Audit Office realizes its activity, including in the field of the control on the public procurements only according to a plan on the grounds of an Annual programme for the audit activity. The National Audit Office does not carry out audits as per complaints and claims (requests) by state bodies, natural persons and/or legal entities. Solely the National Assembly in Bulgaria has right to assign to the National Audit Office the carrying out of up to 5 audits annually. The checkups of public procurements within the framework of a concrete audit are carried out on the grounds of an excerpt. The excerpt includes only the procedures and the other actions as per assigning (public invitations, free assigning), which are carried out through the audited period and shall be checked at the audit. When the number of the assigned public procurements for the audited period is insignificant is carried out a complete checkup.

The established by the auditors during the checkups of the included in the excerpt procedures or other actions as per assigning, including the established administrative violations, are reflected in a project of an audit report. In it are also included recommendations for elimination of established weaknesses, omissions and violations, including in the field of the public procurements.

The following conclusions and recommendations can be accepted on the grounds of everything exposed up to here:

1. The government supervision influences on the business environment and on the activity of the enterprises directly and indirectly. Directly, through the control actions and indirectly, through the formal presentation, announcement and publishing of the results from the activity of the supervision and control institutions.

2. The government supervision influences on the proper execution and observance of the accounting standards, which respectively is a precondition for minimization of the financial frauds and misuses.

3. The government supervision influences on the development of the investment projects through the means and methods of the supervision. 


\section{REFERENCES}

A., \& Anang, F. (2010). Internal Financial Control Procedures in Second Cycle Institutions. Unpublished Dissertation, 8, 9-10.

Allen, M., \& Thompson, B. (2008). Cases \& Materials on constitutional \& Administrative Law (9th edition) 2008. Oxford University Press, p. 45.

Bush, T., Heichlinger, A., \& Klausen, K. (2013). Public management in the Twenty first Century, trends, ideas, practices. Universities for laget, Oslo, Norway, p. 47.

Ekonomske Teme - Nish (2005). № 1-2.

Gunn, S. (2009). Risk and Financial Management in Construction. Gower Publishing, Ltd., p. 63. Iddrisu, Koleva, V. (2005) Management by Objectives Application as Instrument for Performance Management within the System of the Ministry of Internal Affairs (In the Context of EU Integration).

Manliev, G. (2017). The New Management in the Public Sector. UNWE, p. 27

Menifield, C. (2013). The Basics of Public Budgeting and Financial Management: A Handbook For Academics And Practitioners. UPA, 2 edition, 56.

Nedyalkova, P. (2014). Methodological Foundations of the Assesment of Internal Audit. Izvestia. J. of Univ. of Econ. - Varna, 1, 65 - 80.

Nilsson, F. (2015). Financial Accounting and Management Control. Springer International Publishing, p. 65

Shim, J. K., \& Siegel, J. G. (2016). Corporate Controller's Handbook of Financial Management. CCH Inc., p. 47.

Shiplett, M. (2008, November). Innovations in Human Resource Management: Getting the Public's Work Done in the 21st Century, editors Terry Buss, PhD, Myra Howze Shiplett and Hannah Sistare, National Academy of Public Administration, M.E. Sharpe. 